\title{
UNIVERSITY COLLEGE, SOUTHAMPTON DEPARTMENT OF ZOOLOGY
}

$\mathrm{P}$ ROF. J. Z. YOUNG, professor of anatomy, University College, London, opened the new Department of Zoology at University College, Southampton, on December 5. In an address before the opening ceremony, which was attended by representatives of universities and other bodies, Prof. Young pointed out that although there are many reasons for the study of zoology, tho most important is to satisfy our urge to become acquainted with the animals around us. He emphasized the richness of animal life still to be found in the British Isles, and suggested that the great abundance and variety of life in freshwater ponds and streams, and even more especially in the sea, should merit our particular attention. With the importance of the fishing industry in Great Britain, it is clear that the study of marine life is of very considerable practical value. Prof. Young expressed the hope that the new Department would study animals in relation to their environment. At the same time experimental zoology, experimental embryology, anatomy and other methods of approach, he said, are essential to the study of the animal as a whole. In this connexion he welcomed the emphasis which is being placed in the new Department on comparative physiology. Even man and his environment may be regarded as a proper subject (though admittedly a very complex one) for zoologists to study. Thus the zoologist should be prepared to extend his thinking to anthropology and related subjects. But whereas on one side the study of zoology may march with philosophy, on the other hand it is just as needful, if we are to understand the working of animals fully, to enter the fields of biochemistry and biophysics. Zoology is therefore a fundamental science and at the same time an allembracing subject requiring the most severe mental

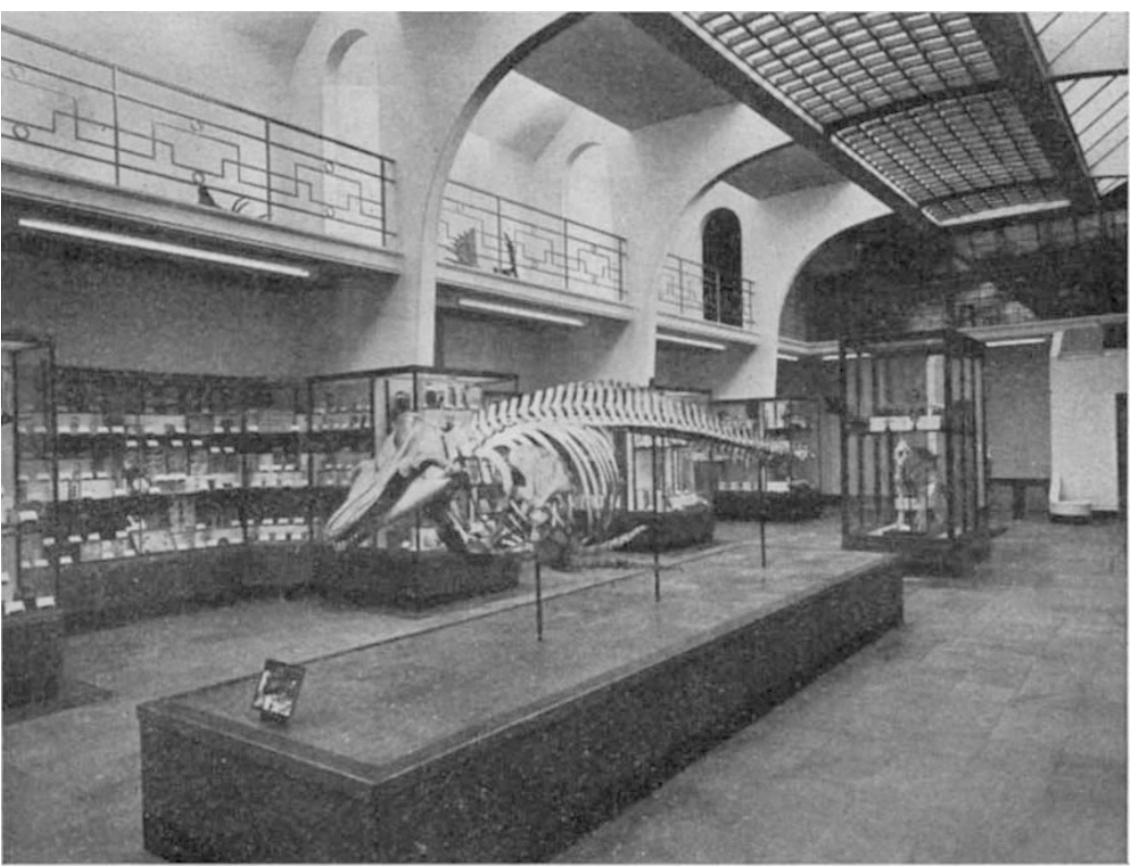

Zoological Mnseum, University College, Southampton discipline. He hoped, therefore, that in Southampton zoology would not be too narrowly interpreted. The new and well-equipped laboratories, he said, mark an important step in the development of the subject with which Southampton can make a real contribution to biological studies.

The new Department is a well-designed building of two floors, built of brick, and some $130 \mathrm{ft}$. long. It has been added to an existing block which once housed both the Geology and Zoology Departments, and between the old and new buildings a new zoological museum has also been erected.

The whole Department has been supplied with teak benching, and care has been taken in planning extensive cupboard, shelf and drawer accommodation. All laboratories and private rooms have been provided with ample electric power points. It has been possible also to provide microscopes, low-power binocular microscopes and general equipment for each laboratory in numbers sufficient to make each almost a self-contained unit.

On the ground floor the new Department houses a well-equipped physiology laboratory. This includes benches designed for kymograph work, as well as chemical and embedding benches and a smoking and fume cupboard. Near by is a dark room reserved for physiological work. Apart from general equipment, the physiology laboratory is furnished with recording apparatus, refrigerators, a Spekker photoelectric absorptiometer, direct-reading balances and a respiration bath.

Across the corridor from the physiology laboratory there is a well-ventilated and lighted animal house with stocks of 'pure line' rats, mice and guinea pigs housed in racks of metal cages. Special heated aquarium sinks also maintain a colony of 250 South African toads (Xenopus). These are being used mainly for research on the pituitary and the physiology of colour change. The mammal stocks are used for research into growth hormone, adrenocorticotropic hormone and other endocrine gland effects, and also as stock for teaching purposes. Both the animal house and the nearby preparation room, which is fitted with a large tiled dissecting slab and work bench, have concrete floors to facilitate washing.

There is a cold room of generous proportions which is capable of giving constant temperatures $(c . \pm 0 \cdot 5)$ from $0^{\circ} \mathrm{C}$. up to room temperature. This is made possible by a large refrigerating unit and system 
of fans and ducts to circulate the cold air. The room is insulated throughout by a double layer of cork, faced with white polished asbestos boarding. Daylight is admitted by a vacuum-insulated window; but the room can rapidly be converted into an experimental dark room with controlled lighting. Three large concrete tanks with heating units have been built into the cold room so that constanttemperature baths at different temperatures can be operated at any one time.

An aquarium room with compressed air supply is also situated on the ground floor. Both the aquarium and cold rooms are already in use for experimental work on marine and freshwater animals. The aquarium room includes two large slate storage tanks for living animals, in addition to the usual small tanks.

The new building is equipped with a departmental photographic dark room and a small developing room. Equipment in the photographic room includes an optical bench with photomicrographic apparatus and an enlarger for both micro-film and ordinarysize negatives.

The ground floor also has three lecturer's rooms, a technician's room, a large research room occupied by two postgraduate students and a room equipped with sterilizing ovens and an autoclave. Store rooms for glassware, chemicals, general equipment and one for nets and other ecological apparatus complete the ground floor. A small lift for goods serves both floors of the building.

On the upper floor, apart from the professor's room, two lecturer's rooms and a research room, there are three laboratories, two of which, planned to accommodate about thirty students each, form part of the old block. The remaining now laboratory has been planned as a 'final honours' room, designed to take a dozen students. Each student has ample bench and cupboard accommodation, and the room has also been fitted with a small lectern and blackboard so that it can be used as a lecture and discussion room.

There is a small lecture theatre, capable of seating some sixty students and fitted with an epidiascope which can be sunk into the lecture bench, and also a departmental library equipped with steel shelving to take about four thousand volumes and with study space for about a dozen students. This library houses the majority of the zoological books in the College, and also includes a good selection of full runs of the more important journals in both zoology and physiology.

The new departmental museum, of modern design, measures some $70 \mathrm{ft}$. $\times 35 \mathrm{ft}$. It is lighted by a glass roof supported by four main reinforced concrete arches spaced along the length of the room. A narrow gallery, with 'Lenscrete' panels in the floor to increase the lighting, runs along three sides of the museum and is reached from the upper floor of the Department. The concrete arches mark off bays at the groundfloor level of the museum, and glass display cases, $7 \mathrm{ft} .6$ in. high, framed with Australian walnut and bronze fittings, have been placed around the walls and bays. Heating units have been sunk into the lower parts of the cases.

The sliding glass panels give excellent views of the collections displayed. Both the day lighting and the fluorescent lighting, hidden largely in the glass roofing, have been specially planned to minimize reflexion from the glass of the cases.

The museum collections are arranged phylogenetically and include dissections and skeletal prepara- tions, many of which have been made by students of the Department as part of their course work. Many specimens have also been generously given by other departments and museums. It is hoped that the museum, though designed primarily as a teaching museum for the Department, will also serve as a centre for the colleges and schools in the area, since Southampton lacks a municipal natural history museum.

The gallery has at present only storage cases housing a large part of the smaller specimens used for general class purposes; but it is hoped that further display cases will be added there in the near future.

The centre of the museum is occupied by a few of the larger exhibits, including an $18 \mathrm{ft}$. long skeleton of the pilot whale, Globicephala, which was prepared last year in the Department from one of the specimens stranded on the beaches at Dunbar. While the present collections are mainly systematic and morphological, ecological and other exhibits are planned for the future.

The new Department was viewed by visitors after the opening ceremony, and demonstrations of the research work now in progress were laid out in the lecturer's and research rooms. They included physiological studies on the endocrine glands, studies on the growth of Mytilus and the infection of Mytilicola, and factors concerned in the hatching and ecology of Chirocephalus. Studies on the respiration of marine Copepoda, and of growth of bones in trout, and some ecological investigations on streams and ponds, and on beech-woods were also demonstrated.

The Department emphasizes ecological work, with the sea and the New Forest area (with its varied streams and woodland) only a few miles away. A small boat is operated in Southampton Water by the Department. At the same time, ecological work is combined so far as possible with experimental zoology. The facilities available for comparative physiology have been planned with the aim of developing this subject both as regards teaching and research.

Students also exhibited some of the dissections and preparations and special studies which they have in progress as part of their normal degree work.

\section{BRITISH FOOD MANUFACTURING INDUSTRIES RESEARCH ASSOCIATION OPENING OF NEW LABORATORIES}

I ADY ENGLEDOW, wife of Sir Frank Engledow, 1 Drapers' professor of agriculture in the University of Cambridge, on November 8 cut a ceremonial ribbon stretched across the entrance and declared open the fine new laboratories at Leatherhead of the British Food Manufacturing Industries Research Association.

The Association was formed in the beginning of 1947 by the amalgamation of two much older research organizations. Although nominally only in its fifth year, its work, which covers a broad (and everwidening) field of food processing and preservation, is a continuance of research that has been developed during the past thirty-two years. In 1919, the British Association of Research for the Cocon, Chocolate, Sugar Confectionery and Jam Trades was formed as 